\title{
HANDLING SUB-SOIL URBAN ARCHAEOLOGICAL RESOURCES IN URBAN PLANNING, ISSUES IN İZMIR HISTORIC CITY CENTRE (1)
}

\section{Burak BELGE*}

Received: 08.05.2012; Final Text: 18.09.2012

Keywords: ideal and real urban archaeological potential; İzmir historic city centre; multi-layered historic city centres; diachronic plans; equi-property areas; urban archaeological character zones.

1. This paper is an up-dated overview of author's M.CP. Thesis, "Urban Archaeological Issues and Resources in İzmir Historic City Centre: An Exploratory Case Study" (Belge, 2005), focusing on handling of urban archaeological resources in planning that was completed with the supervisor Prof. Dr. Numan Tuna at METU.

\footnotetext{
* Faculty of Architecture, Mersin University, Mersin, TURKEY.
}

In Turkey, although most of the historic city centres have been continuously occupied since early ages, urban archaeological resources -cultural deposits underneath modern cities- could not be handled into planning process. It will be possible to strike the right balance provided that the archaeological resources are evaluated and considered in each stage of the planning and development process. At that point, urban archaeology is considered as an interdisciplinary field of study that evaluates the cultural stratification in cities and understands the historical background of urban life, while urban planning is a decision-making process on the development of urban areas and planners as a mediator between actors with varying interests.

In any case, since the earliest stages of the planning process, as a necessity, urban planners should be well-informed about the urban archaeological resources, but the most of urban planners in Turkey are not still well equipped about archaeological resource management in historic city centre. There are instances when, the incapacities caused even the deliberate destruction of urban archaeological resources, deliberately. Tuna (1999, 222) points out another dimension of dilemma, as urban archaeological resources are mostly seen as obstacles that should be eliminated or ignored for urban development in the Turkish planning experience.

In a defined context, evaluation of real archaeological potential in historic city centres is one of the crucial problems in handling of archaeological resources. Especially archaeological resources underneath modern cities could not be identified effectively because of varying incapability in the databases and spatial analysing methods.

International interest has increased on the specific topic of the dilemma between archaeology and planning since 1980s. While international suggestions are developed for the conservation and enhancement of the archaeological heritage as a matter of urban and regional planning policies, national legal and administrative frameworks have been developed for 
2. There is a huge literature about the relation between archaeology and planning. For further discussions Delaunay (1984), CoE (1989), Hester (1989), ICOMOS (1990), PPG-16 1990, CoE (2000), Addyman (2003), EC (2006) (APPEAR), PPS-5 (2010), will be examined in detail. Furthermore, there are unpublished thesis studies in Turkey. Alpan (2005), Aykaç (2008), Belge (2005), Bilgin (1996), Bilgin (2002) and Çırak (2010) shall be helpful for detailed understanding of the situation of urban archaeology in Turkey. Moreover, Kılıç and Gülbay (2010) underline a different dimension in urban archaeology bases on totally destructed archaeological remains in İzmir, which could be followed by the assessment of ancient travellers' statements and archaeological comparisons. the integration of archaeological resources to planning process. These documents (2) underline the lack of a prior understanding between archaeologists and planners, who are seen as natural enemies (Hester, 1989,233 ) and enhance the crucial role of an archaeological database in the planning process to prevent archaeological remains from irreversible destructions.

Therefore, the study describes a simple framework to handle sub-soil urban archaeological resources into the planning processes by means of urban archaeological databases and spatial analysing of varying sets of data.

\section{THE METHOD OF STUDY}

The method of study is based on evaluation of real urban archaeological resources - possibly conserved heritage- in multi-layered historic city centres. Garmy $(1995,3-8)$ enhances the urban continuum term that used in terms of topographical and chronological components instead of highlighting specific elements in cities and defines an approach is different from a basic inventory. The approach looks for "real" heritage resulting from a long series of interventions that creates gaps in an ideal heritage determined by historical development.

In this context, the formula $\operatorname{Pr}=(\mathrm{Pi}-\mathrm{D})^{\mathrm{q}}$ is basically defined to determine real urban archaeological potential. In the formula, "Pi" is theoretically the successive occupation of the city and its topohistorical development. " $\mathrm{D}$ " means the massive destruction of archaeological strata by varying factors " $\mathrm{q}$ " is directly related with the quality of archaeological deposit that determined by topographic factors, archaeological sites' capacity to preserve material and the extent of cultural deposit (Garmy, 1995, 3).

In Turkey, although there are different datasets on urban archaeological issues and planning process, these data are stored in different institutions in varying format. There is no chance to use them as a base for the decision making / planning processes. Therefore, the study, firstly, concentrate on how different sources of information can be formatted in spatial terms to set planning base. An Urban Archaeological Database (UAD) can process different sources to allow set ideal urban archaeological potential is a crucial point in the methodological framework.

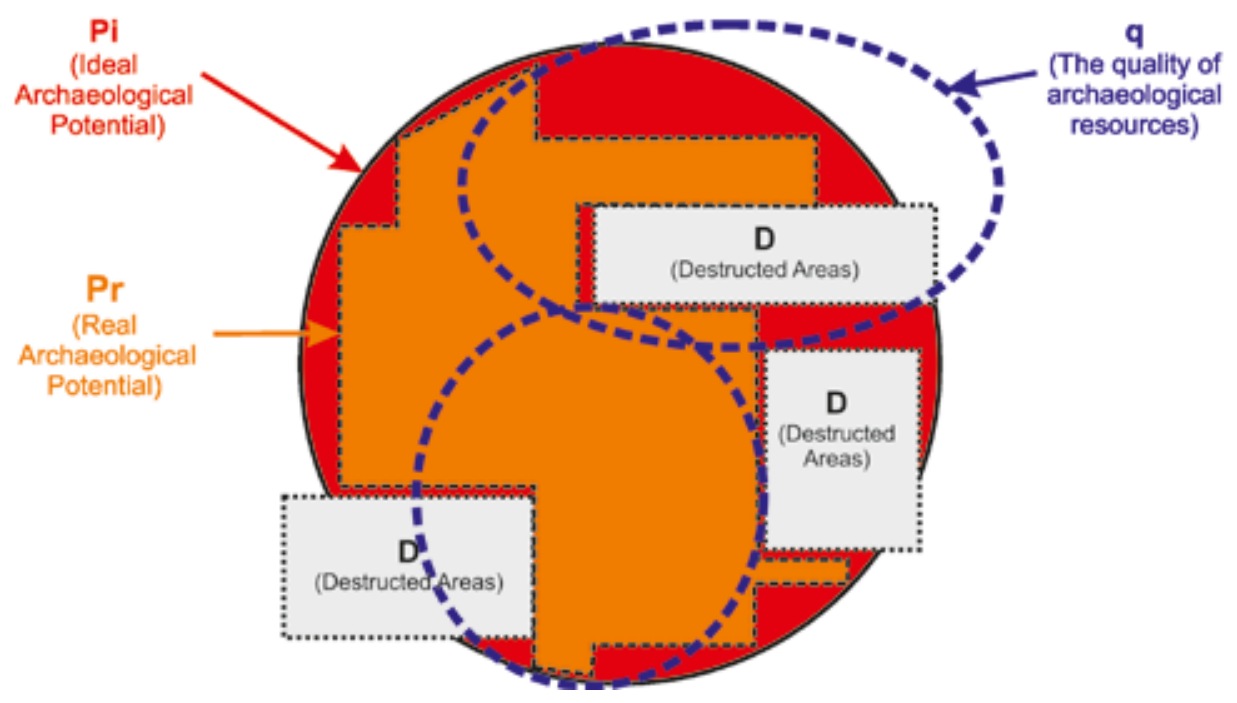


3. There are varying GIS Programs -open or closed sources systems- to set an Urban Archaeological Database. Beyhan (et al. 2010) presents a comparison between free and open source programs with advantages and disadvantages.
Thus, in this context, primarily, how historical and archaeological data can be uploaded to UAD is discussed. Reliability of data is crucial to determine primary and secondary sources of information and their possible use. Then, partial or massive destruction on urban archaeological resources are studied in detail. After that, the conservative factors on urban archaeological resources like topographical, or the site's capacity to preserve material, are studied. The evaluation of the real archaeological potential and definition of urban archaeological character zones is the last stage of the method. These evaluations may simply be followed by Figure 1.

Consequently, the study discusses not only preparing UAD, but also a basic frame for the handling of the sub-soil urban archaeological resources into planning process. Therefore, possible outcomes of the method and features of UAD have been emphasized with a case study, at the İzmir historic city centre.

\section{URBAN ARCHAEOLOGICAL DATABASE}

Urban Archaeological Database in this study is not an "Urban Data Bank" which usually includes varying level of data from historical documents roughly to set a city museum or archive. It should be just seen as a GIS based model that is used for spatial referencing of varying datasets. There are varying alternatives based on Geographic Information Systems (GIS) programs (3) let to link graphic/spatial data and related database. Wheatley and Gillings $(2002,234)$ assume a two branch in use of GIS for archaeological studies. First branch includes database and cultural resource management. Second one, the research branch compromises regions and intra-site studies. The UAD model used in this study can be evaluated within the scope of the management branch. The UAD led to spatial evaluation of topographic and geographical elements, archaeological and historical data, and destruction on urban archaeological resources or site features in the preservation of urban archaeological resources.

Real urban archaeological potential could be evaluated by superimposition of the aforementioned datasets. Maybe, superimposition does not let to determine unique or the homogeneous archaeological potential, but planners may have more detailed view on urban archaeological character zones in different categories, to define appropriate policies by coding.

\section{IDEAL ARCHAEOLOGICAL POTENTIAL IN THE IZMIR HISTORIC CITY CENTRE}

Ideal Archaeological Potential could be defined theoretically as probable archaeological resources without any destruction. Therefore, firstly, archaeological and historical data about the İzmir Historic City Centre are researched to define primary and secondary datasets according to their reliability. After that, diachronic reconstruction plans are prepared for each period in relation with socio-economic history of İzmir. Consequently, equi-property areas in İzmir Historic City Centre are determined.

\section{Primary Datasets}

Primary sources can be regarded as the first hand data on archaeological resources. Archaeological excavations are one of the scientific works including detailed reports, plans, sections and assessments on artefacts. This data will be used as a direct input to understand the accumulation 
of cultural layers horizontally and vertically. In the İzmir Historic City Centre, although there are various traces of ancient monumental structures, scientific archaeological excavations have continued in only the State Agora, which is known as Namazgah from the beginning of the 20th century on. Another important monumental structure studied in the Early Republican Period is the Theatre of Ancient Smyrna. There are restitution drawings of the Theatre prepared in 1922, when the traces of the Theatre were still visible. In addition to the archaeological excavations, Nauman and Kantar $(1950,71)$ prepared a map of known ancient structures by visible archaeological remains and using old maps such as Luigi Storari's Map.

Another primary dataset is the inquiry soundings, trail trenches and basic documentation on findings by chance that are established especially in the rescue works. In Turkey, there are problems in documentation because of scarce time and financial resources. Therefore, the dissemination of information resulting from field work would not be easily obtained. Moreover, the records on inquiry soundings and trial trenches carried out even in the recent past are not available to be used (Tuna, 1999, 220).

Archaeological surveys constitute another primary dataset. The aim and scope of archaeological surveys are different in archaeological terms. However, in urban archaeological terms, surveys should be seen as nondestructive and quick data collection method. The surveys may aim either an overall understanding of recent structures or detailed research on urban archaeological traces. Extensive, intensive and non-destructive archaeological surveys are possible. Intensive and non-destructive survey methods like geophysical surveys can be carried out to examine archaeological and historical data on the plot base. However, because of limited resources, intensive methods are not used in this study.

The extensive survey is carried out in the İzmir Historic City Centre to understand basic components, including types of urban pattern and building. Survey is supported with aerial photo and base map to determine sub-zones according to pattern analyse and building types. Consequently, morphed grid-iron pattern, conserved traditional pattern, planned area after 1922 and modern pattern are described. Also, urban parks and big vacant areas were examined. According to basic surveys; there are mainly four building types, the traditional houses, the aarly Republican buildings, modern buildings and squatter housing within the study area.

Furthermore, old maps and photographs are another group of primary datasets. Since the second half of the 19th century, the maps of İzmir and its surroundings have been prepared parallel with westernization movements in İzmir. The reliability and sensitivity of maps are so different because of technological differences. However, even maps were produced in various systems, known structural elements of city such as Kadifekale and conserved axes are used to rectify the old maps into current coordinates of UAD. Especially, maps that show the general layout and basic elements of İzmir were preferred to prepare Diachronic Plans. This data has become so helpful to examine the periods since 1850s. In this context, the maps of Thomas Graves in 1836-37, Luigi Storari in 1854-56, Georgiades in 1885, the Water Distribution in 1897, the Ministry of Defense in 1925 and Emin Canpolat in 1950 were studied in detail. All mentioned maps were rectified firstly, then used as layers for the Urban Archaeological Database. 
4. Especially, there are detailed references for ancient structure and occupation area in the writings of Pausanias, Aristeides, Strabo and Pionious (Cadoux, 1938).

5. Pınar (2001) prepared a detailed research about travellers visiting İzmir from 1608 to 1918. Although there are problems on the references of visual documents like engravings, research allows having clues about physical references, socio-economic information like demographic data and visual documents.

\section{Secondary Datasets}

Secondary sources are visual or written historical documents like traveller's books, engravings and sketches obtaining information of different periods and draw an image of city; even they are not designed for this aim. Bilgin $(1996,45)$ underlines the degree of reliability of these documents, because of possible wrong or inexisting information.

There are detailed sketches of İzmir and engravings by travellers including hints from the periods of their presence. Of course, they are only images of periods, but they will be used to enhance known structures by visualization. Moreover, ancient writer's statements (4) or traveller's books (5) include spatial references. So, chronological documentation of the statements topic by topic lead us to understand socio-economic development in İzmir.

\section{EVALUATION OF IDEAL URBAN ARCHAEOLOGICAL POTENTIAL}

As defined, Ideal Urban Archaeological Potential would be evaluated by superimposition of the successive occupations of the city and its topohistorical development. Therefore, the occupation areas in different periods have to be determined.

Sommella $(1984,3)$ defines utilizable documentation as an interdisciplinary study with the assistance of specialists in the fields of ancient history, archaeology, town planning, topography, history, epigraphy, numismatics etc and co-operation between them to achieve a comprehensive understanding of an urban environment by means of horizontal and vertical cross-sectional analyses. Bilgin $(2002,34-40)$ points out that, a utilizable documentation can only be achieved by diachronic documentation. In diachronic documentation parts of structure is crucial. Cohen $(2001,36-7)$ indicates needs to brake down city into most basic components to understand in-depth defines.

The contents of diachronic reconstruction plans are various about the elements of general layout and inner organization of cities. Occupation area, boundaries, gates and urban division are crucial in the diachronic maps. These elements have to be studied in detail for each period to understand the structure of the city. For our case, six diachronic plans are prepared for İzmir historic city centre.

\section{Diachronic Plans}

Each period of the successive occupations of İzmir and its topo-historical development studied by diachronic reconstruction-plans are prepared by primary and secondary layers in UAD. In earlier periods, archaeological datasets are supported by ancient writers' statements. Old maps are the most usable datasets to understand the periods of the 19th century. In the 20th century, planning works and comments on modern development were helpful to prepare diachronic views. While, all diachronic plans are preparing, sub-zones are determined to observe continuities and discontinuities in the general layout of the historic city centre. Furthermore, artificial and natural changes in the coastline are evaluated as an issue in each diachronic plan.

However, diachronic plans of the historic city centre are prepared through insufficient material for some period. Because, though there are earlier archaeological and historical studies in İzmir, only some of them give 
Figure 2. The old and new locations of settled area in Izmir (prepared by the author using recent base map and Canpolat's map (1953) indicating ancient coastline.

Figure 3. The recent boundaries of different categories of conservation sites (İzmir Metropolitan Municipality, Directorate of Historical and Cultural Properties). detailed information about the inner organization of İzmir Historic City Centre. Therefore, special regions, where main urban elements and buildings do concentrate or important axes do coincide continuities and discontinuities in the inner organization with functional or social concentrations are determined.

Diachronic reconstruction plans are prepared for historical periods that are determined according to the turning points in the socio-economical history of İzmir. Therefore, diachronic plans lead us to understand full history of the city by means of horizontal and vertical cross-sectional analyses described by Sommella $(1984,2)$.
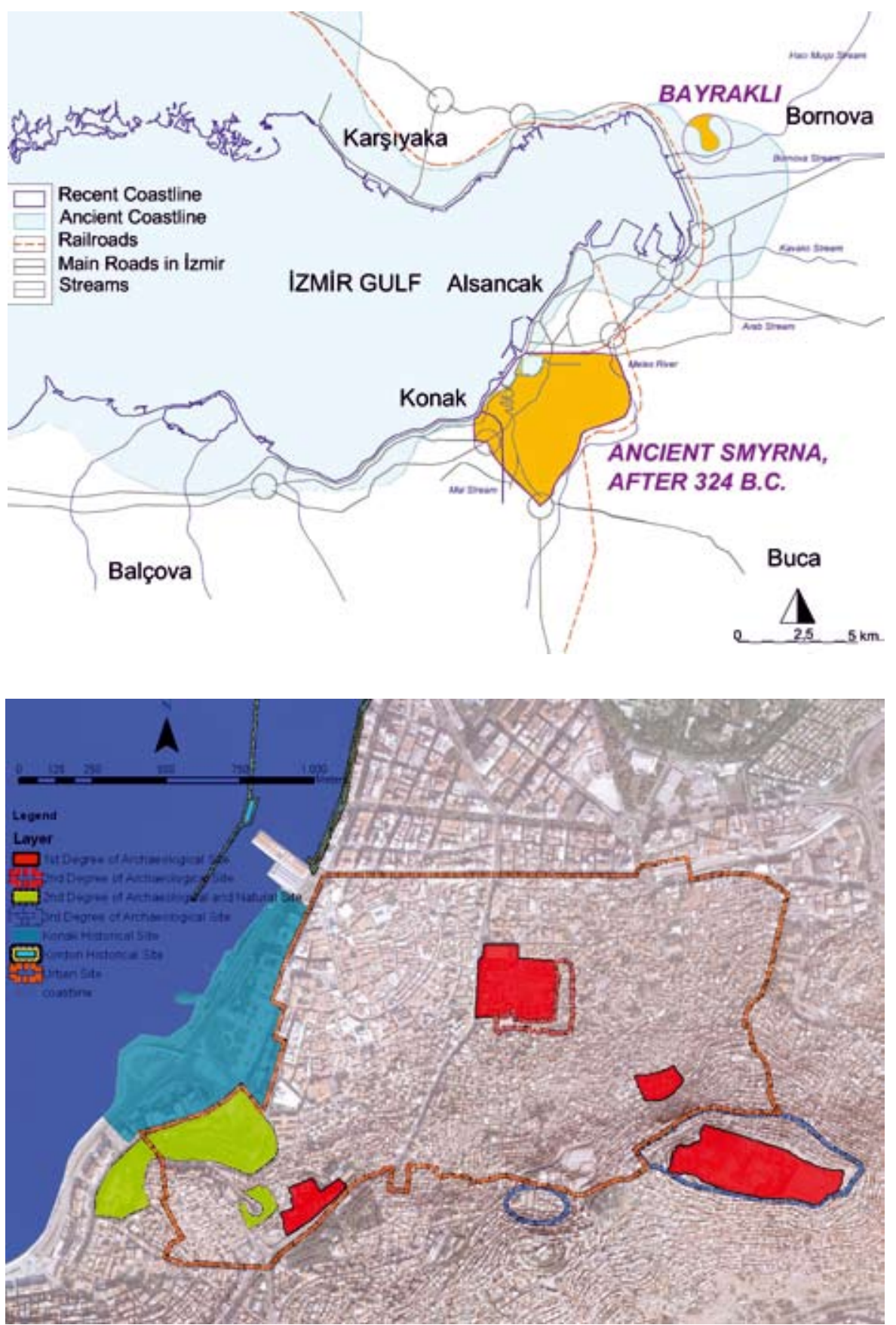
İzmir and its region are inhabited continuously since 4000 BCE. (Alkın, 1968 cited in Kuban, 2001, 54). First settlement area was Tepekule (at the innermost site of İzmir Gulf and presently called as Bayraklı) in İzmir Metropolitan Area and there are artefacts from 3000 BCE in that site (Akurgal, 1970, 119, cited in Kuban, 2001, 54). The Lydian destroyed and emptied Smyrna, because of its commercial and agricultural activities in Hermos (presently called as Gediz) Valley at the end of the 7th century BCE. There are archaeological evidences claiming that peoples had returned Smyrna / Bayraklı since 580 BCE. (Bean, 1966, 50 cited in Kuban, 2001, 57). Re-foundation of Smyrna between Mount Pagus and Aegean Sea was explained by a legend on dream of the Alexander Great in 334 BCE. After re-foundation of Smyrna, Lysimakhos -one of the commander of Alexander the Great- built-up city that embraced by the walls (Cadoux, 1938, 100-5).

This area is selected for case study, bounded by Kadifekale - Değirmentepe axis at south, Punta at north, changing coastline in time at west and tentatively Meles River at east. It could be defined as probable occupation area of Roman Period, when İzmir had reached its largest boundaries in the antiquity. The occupation area of İzmir has been enlarging than Roman period since 1800s. However, defined study area has become the core of İzmir and periphery since the re-foundation of city in 324 BCE. (Figure 2).

Recently, because of multi-layered accumulation, different categories of archaeological and historical sites had defined in İzmir Historic City Centre. There are "Urban Conservation Site", "1st, 2nd and 3rd Degree of Archaeological Sites" and "3rd Degree of Archaeological Site and Urban Site" together. The boundaries of archaeological sites are roughly determined within a reference to monumental structures or known archaeological sites like the State Agora, the Theatre, the Stadium or Roman Road (Figure 3). However, the boundaries don't reflect real archaeological potential exactly discussed in the latter sections in detail.

In diachronic documentation, the first period began with the re-foundation of İzmir in 324 BCE, continued with the Roman Republican Period -the most brilliant period- of the city and ended with the Byzantine Period in the 7th century BCE. Especially ancient writers' statements are used to determine the general layout and the inner organization of the city, because primary datasets are not clear to determine a diachronic reconstruction plan. However, primary datasets especially rescue works used for supporting writers' statements. Consequently, three main division units that are the administrative centre, the housing areas and the outside of fortification walls that as a low occupancy area, are identified (Figure 4).

The second period started with the Byzantine Period and ended with the domains of the Ottoman Empire in the beginning of the 15th cent. Kuban $(2001,61)$ points out that there is so few data on the physical layout of İzmir in the Byzantine Period, that the traces of the fortification walls lead to determine the settlement area of the city. The most important urban characteristic is the dual character of the city as the Upper İzmir and the Lower İzmir. According to this context, the Lower İzmir, the Upper İzmir and the area with low density are determined as sub-divisions (Figure 5).

The third period started with the domains of the Ottoman Empire in the beginning of the 15th century and ended with the westernization movements in the second half of the 19th century. During this period, İzmir had gained importance with the increasing commercial capacity by the 

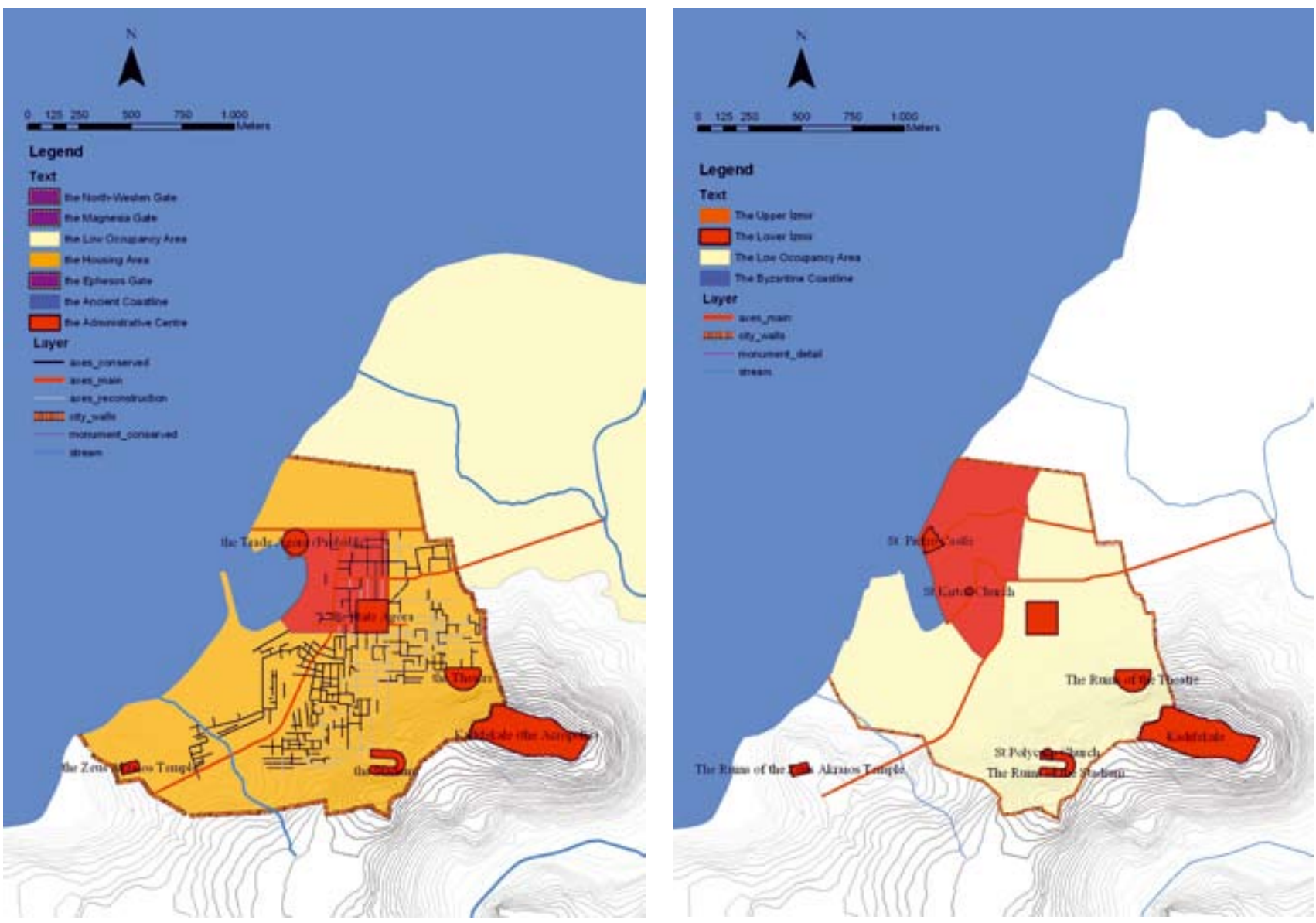

Figure 4. İzmir in Ancient Period (prepared by the author depending on recent base map of İzmir Metropolitan Municipality, the 1854 Map of Luigi Storari (Atay, 1998), and the sketch of Ancient Period (Nauman and Kantar, 1950)

Figure 5. İzmir in Byzantine and Early Turkish Principalities Period (prepared by the author depending on recent base map of İzmir Metropolitan Municipality and the General Map of Early Ottoman Period (Müller, 1963). domain of the Ottoman Empire. Pococke (1771, 5-24, cited in Kuban, 2001, 72) made a description of İzmir with layout like a triangle that lied $1 \mathrm{~km}$ in west-east and $3 \mathrm{~km}$ through the coastline. Inner port was completely filled by alluvial. At the end of the period, general boundaries of the city could be easily traced from the maps of Thomas Graves (1836-37) and Luigi Storari (1854-56). Eight sub-division zones are identified in the Early Ottoman Period as Muslim, Frenks, Greek, Armenian and Jewish quarters and the commercial centre, administrative centre and the cemeteries in various locations (Figure 6).

The fourth period began in the second half of the 19th century and ended in 1922. İzmir had gained its commercial importance with the construction of both railways and the harbour in the second half of 19th century (Özkut, 1997, 27). In 1863, firstly the İzmir-Manisa railroad, and then the İzmirAydin railroad opened. The occupation area of the city can be followed by Georgiades' map in 1885 and the water distribution map in 1897. The maps indicate the northern expansion and the new development pattern around Alsancak and Punta districts in the end of the 19th century. The quarters of different ethnic groups could be still followed in İzmir. Moreover, accommodation services for merchants were developed at the end of the 19th century (Taner et al, 2002, 13) (Figure 7)

The early Republican period started in 1922 and ended with the beginning of rural to urban migration in 1950s. The 1922 Fire destroyed the social, cultural and physical topography of the city. Thus, at the beginning of the period, reconstruction and rehabilitation of the historic city centre was the 

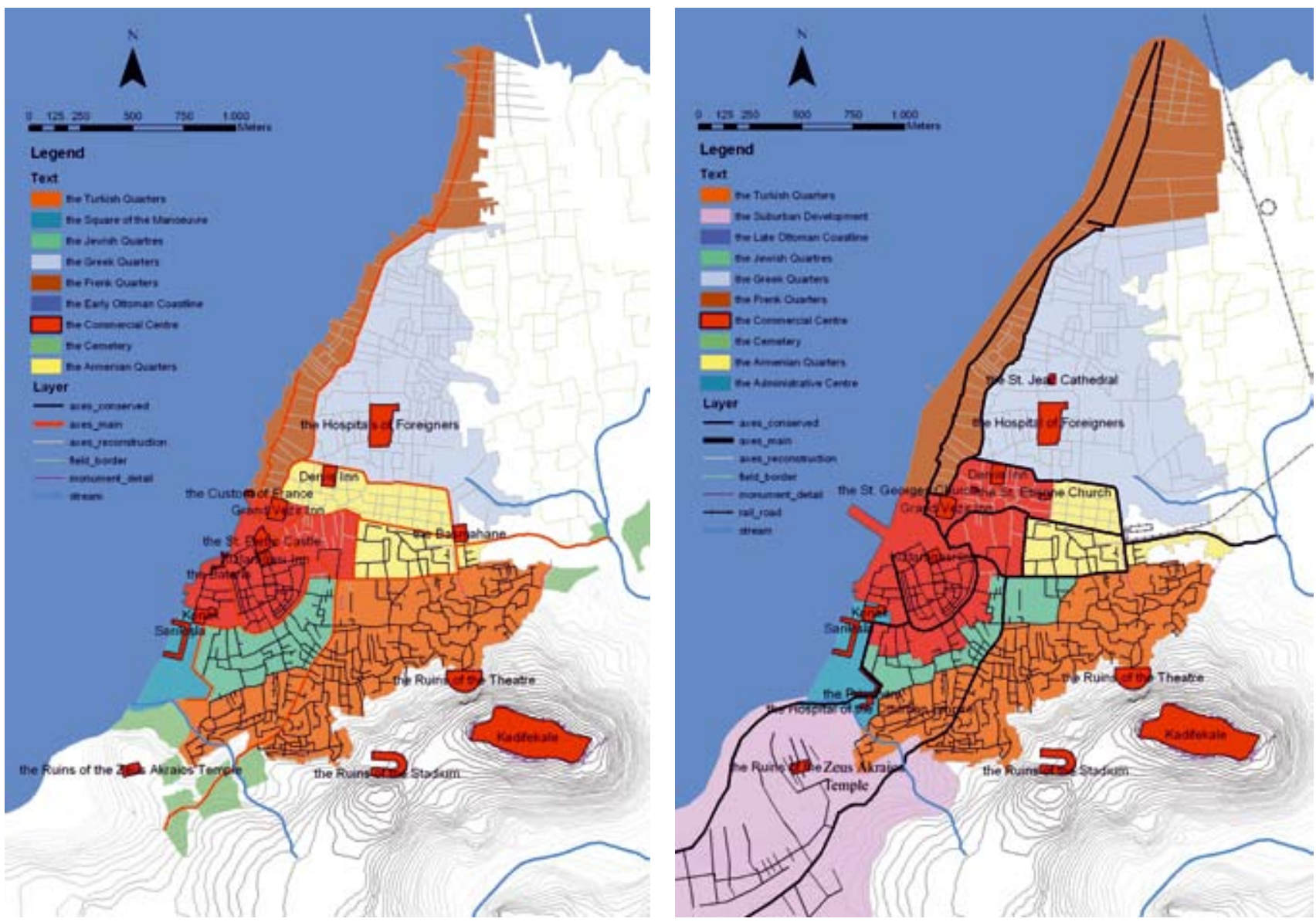

Figure 6. İzmir in Early Ottoman Period (prepared by the author depending on recent base map of İzmir Metropolitan Municipality Thomas Graves's Map (Kuban, 2001) the 1854 Map of Luigi Storari (Atay, 1998))

Figure 7. İzmir in Late Ottoman Period (prepared by the author depending on recent base map of İzmir Metropolitan Municipality, the Water Distribution Map (Başbakanlık Osmanlı Arşivi) and 4696 Numbered sketch (İzmir Büyükşehir Belediyesi, 2003, 69)). main topic. The area between Konak and Alsancak that includes Kemeraltı had formed as the Central Business District. Two different patterns have been emerged as historical pattern and planned pattern with boulevards. Kültürpark is a contribution of the new planned area in the socio-cultural development of İzmir (Taner et al, 2002, 17) (Figure 8).

The last period until now began in 1950's. While İzmir's macroform has enlarged along the Gulf of İzmir and squatter housing existed, historic city centre has gain a dual character including traditional centre and modern centre. Squatters had especially settled at the northern hilltop of Kadifekale. Meanwhile, rebuilding from 2-3 to 8-10 storey buildings was a fact in Alsancak, as a result of increasing land prices and the rental pressure. Konak has been administrative and retail trade centre of İzmir since 1970s (Taner et al., 2002, 18) (Figure 9).

\section{Equi-property Zones}

Sommella $(1984,4)$ suggests a superimposition study known as planovolumetric analyse to determine subzones in multi-layered areas according to stratification and continuity of urban archaeological layer. These sub-zones are identified as "Equi-property zones" has same historical continuity that carries the traces of the same phases (Bilgin, 2002, 118).

In defined context, diachronic documentation of İzmir historic city centre let to more clear insight in the development of the city. At that point, diachronic reconstruction plans will be overlaid to assess whether such areas were settled or not settled in certain periods (Table 1). In 

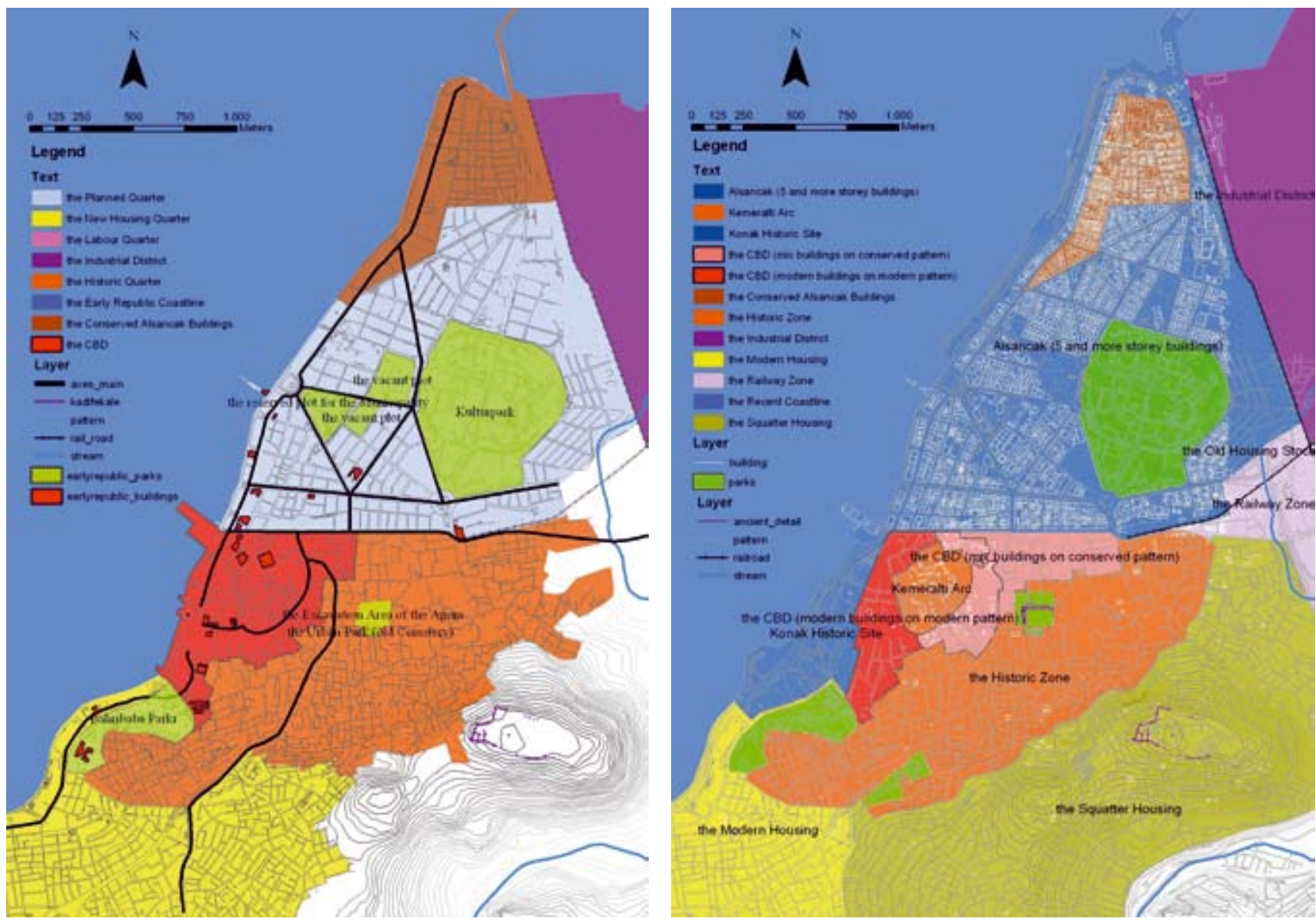

Figure 8. İzmir in 1950s (prepared by the author depending on recent base map of İzmir Metropolitan Municipality and the map of 1950s (Canpolat, 1953)).

Figure 9. İzmir in the Present (prepared by the author depending on recent base map of İzmir Metropolitan Municipality).
6. The term is used by Bertin $(1981,32)$ to define an $x$ / y matrix that allows graphic analysis by the changes of the order of columns or rows to examine the data easier. Bertin (1981, 2-11) summarizes the stages of these types of graphic information processes as simplifying without destroying-interpreting-deciding. Therefore, these types of matrix let us to make spatial analysis by different questions in different levels. other words, diachronic reconstruction plans are overlaid to obtain the degree of stratification. By plano-volumetric view, the equi-property areas are determined according to stratification and to the continuity of urban archaeological layers. These zones are not only areas where similar ideal urban archaeological potential exist by stratification without any destruction, but also where characteristic traces of each period's morphological and functional divisions occur. Consequently, 60 equiproperty areas are defined in İzmir historic city centre (Figure 10).

When these 60 equi-property zones are presented as a table in a chaotic order that should be evaluated as a re-orderable matrix (6) that leads to graphic information processing to easily follow the archaeological stratification. The order of columns in such a table presents a chronological development, so it cannot be changed. However, changes in the order of rows, each one present an equi-property zone, let to examine similarities and differences between them. Re-arranged order of rows allows getting an overall view about the continuities and discontinuities in equi-property zones together. Table 1 and Table 2 indicate a basic example for reordering equi-property areas to classify them. By means of re-ordering, 60 equi-property zones in İzmir Historic City Centre can be classified into main groups. In İzmir Historic City Centre, while some areas were occupied only in a period of time, some others have been occupied since ancient times. 
Table 1. An assumed table depicts the historical stratification in an urban archaeological site. The historical continuity of each zone can be followed by means of such a table. For example, according to this table, Equi-Property Area- 1 had been occupied only in the first and the second periods of the assumed site. This simple presentation technique would be used to understand the vertical and horizontal development of the site.

\begin{tabular}{|c|c|c|c|c|c|c|c|c|c|c|c|c|c|c|c|c|c|}
\hline \multirow{2}{*}{$\begin{array}{r}\text { Periods } \\
\text { Urban Division }\end{array}$} & \multicolumn{3}{|c|}{ PERIOD 1} & \multicolumn{3}{|c|}{ PERIOD 2} & \multicolumn{3}{|c|}{ PERIOD 3} & \multicolumn{3}{|c|}{ PERIOD 4} & \multicolumn{5}{|c|}{ PERIOD 5} \\
\hline & D1 & D2 & D3 & D1 & D2 & D3 & D1 & D2 & D3 & D1 & D2 & D3 & D1 & D2 & D3 & D4 & D5 \\
\hline \multicolumn{18}{|l|}{ Equi Property Area-1 } \\
\hline \multicolumn{18}{|l|}{ Equi Property Area-2 } \\
\hline \multicolumn{18}{|l|}{ Equi Property Area-3 } \\
\hline \multicolumn{18}{|l|}{ Equi Property Area-4 } \\
\hline \multicolumn{18}{|l|}{ Equi Property Area-5 } \\
\hline \multicolumn{18}{|l|}{ Equi Property Area-6 } \\
\hline \multicolumn{18}{|l|}{ Equi Property Area-7 } \\
\hline Equi Property Area-8 & & & & & & & & & & & & & & & & & \\
\hline
\end{tabular}

Settled No Occupation
Table 2. The reordered example table that allows the evaluation of similarities and differences between equi-property areas. Assumed eight equi-property areas in Table- 1 could be classified into four main groups.

\begin{tabular}{|c|c|c|c|c|c|c|c|c|c|c|c|c|c|c|c|c|c|}
\hline Periods & \multicolumn{3}{|c|}{ PERIOD 1} & \multicolumn{3}{|c|}{ PERIOD 2} & \multicolumn{3}{|c|}{ PERIOD 3} & \multicolumn{3}{|c|}{ PERIOD 4} & \multicolumn{5}{|c|}{ PERIOD 5} \\
\hline Urban Division & D1 & D2 & D3 & D1 & D2 & D3 & D1 & D2 & D3 & D1 & D2 & D3 & D1 & D2 & D3 & D4 & D5 \\
\hline & & & & & & & & & & & & & & & & & \\
\hline qui Property Area & & & & & & & & & & & & & & & & & \\
\hline
\end{tabular}

\begin{tabular}{|l|l|l|l|l|l|l|l|l|l|l|l|l|l|l|l|}
\hline Equi Property Area-8 & & & &
\end{tabular}

\begin{tabular}{|l|l|l|l|l|l|l|l|l|l|l|l|l|l|l|l|}
\hline Equi Property Area-2 & & & & & & & & & & & & & & & \\
\hline Equi Property Area-4 & & & & & & & & & & & \\
\hline
\end{tabular}

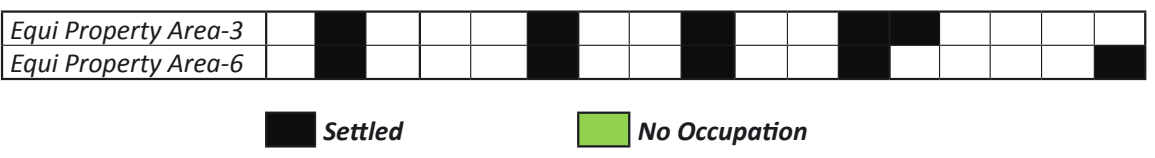

4

\section{DESTRUCTION ON URBAN ARCHAEOLOGICAL RESOURCES}

Evaluated data above optimises the urban archaeological potential and determines ideal urban archaeological potential in the İzmir Historic City Centre. However, archaeological resources have been destroyed by various reasons by the time. According to the methodological equation $\mathrm{Pr}=\left(\mathrm{Pi}^{\mathrm{i}} \mathrm{D}^{\mathrm{q}}\right.$, to evaluate real preserved archaeological potential, destruction (mass or partial) have to be properly examined. Therefore, destructions on urban archaeological resources in İzmir Historic City Centre by re-use, disasters and modern construction methods have to be studied.

Firstly, the destruction by re-use meaning the destruction of structures and artefacts of earlier cultural deposits by the following urban activities is examined. While equi-property areas are assessed according to continuity and cultural accumulation, the risk of destruction in the layers of earlier period are established. At that point, it is crucial that, defined factor is only an assumed destruction. At defined context, the archaeological works in equi-property areas 2 , 6, 20, 21, 22, 23, 26, 27, 28, 32, 41, 42, 46, 47, 48, 49, $50,51,52,53,54,55,56$, that have been occupied during all periods, may be evaluated in detail for testing this assumption.

Secondly, although the exact results of earthquakes cannot be estimated, the consequences of known earthquakes are evaluated. In addition to earthquakes, the effects of fires that either follow the earthquakes or have occurred by themselves have been examined. There is no detailed information about all of the earthquakes and fires in İzmir Historic City Centre. However, there are detailed and spatial references on the 1844 and 1922 Fires. These fires and prepared plans for ruin areas are important in 

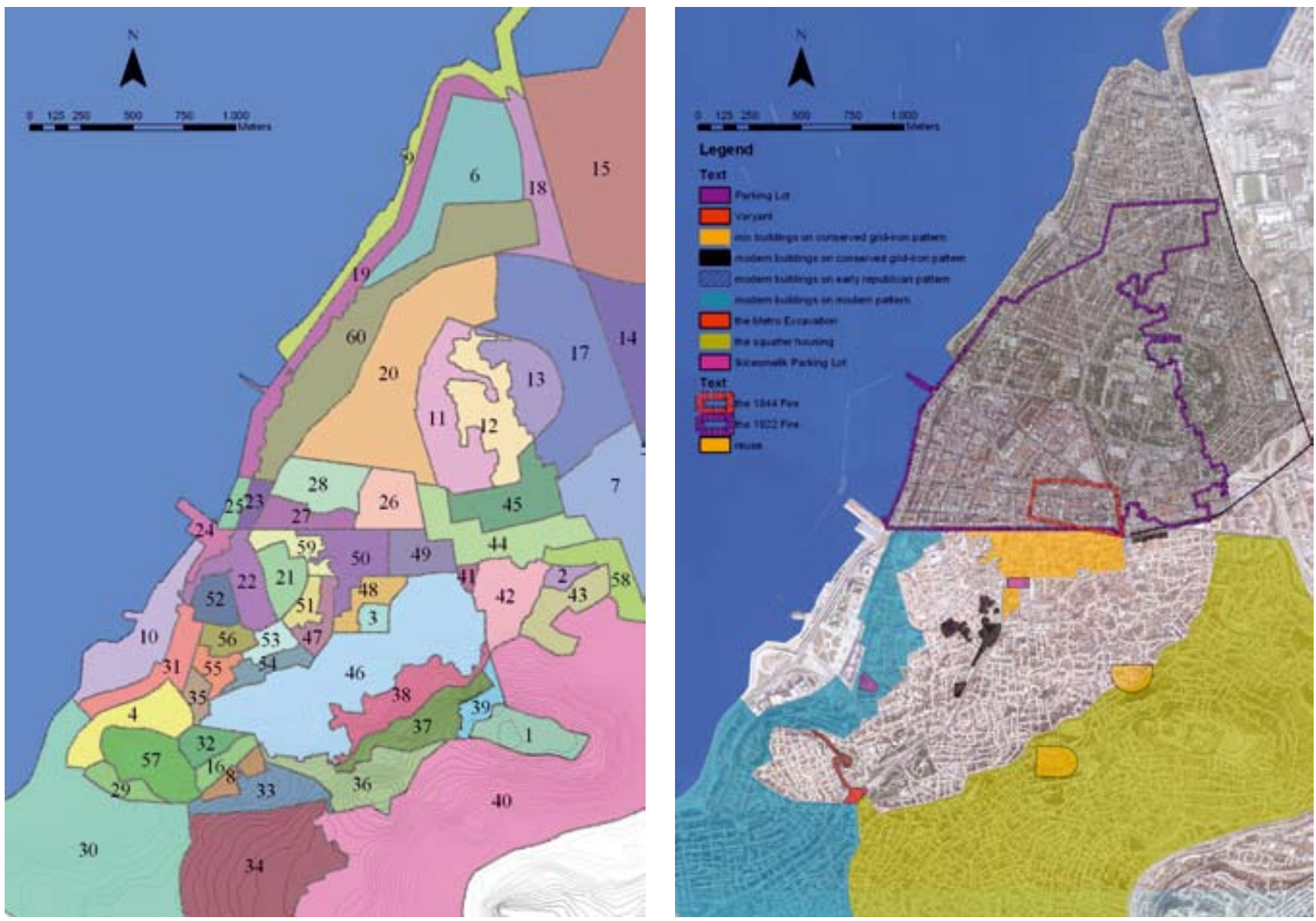

Figure 10. Equi-property areas in İzmir Historic City Centre.

Figure 11. Destruction by Re-use, Disasters and Modern Developments in İzmir Historic City Centre. the continuity of urban archaeological resources. Especially, urban pattern in fire areas had been completely changed.

Lastly, modern buildings are evaluated as a massive destruction with their construction methods and high foundation depths. According to basic extensive surveys in İzmir Historic City Centre, the plots of buildings, which have been constructed by modern techniques since the beginning of early Republican Period, are evaluated as the destroyed areas, where archaeological deposits are completely lost. However, the results of extensive surveys are only sufficient to make an overall zoning in İzmir Historic City Centre. The exact location of destruction should be evaluated by intensive surveys, for, although new modern buildings constructed in its plot, there are vacant / not-settled areas like gardens or streets within these zones.

Furthermore, infrastructure and development projects that destroy urban archaeological resources in İzmir Historic City Centre are investigated. For example, the İzmir Metro Project that caused many discussions on the urban agenda, unfortunately don't includes required scientific documentation. Only movable properties were conserved and some of them have been exhibited at Basmane Station. However, the metro project could not be seen as a successful project, if it is compared with examples from world, say the Athens Metro Project (Tuna, 2003; Fouseki and Sandes, 2009) (Figure 11). 


\section{THE QUALITY OF DEPOSIT IN IZMIR HISTORIC CITY CENTRE}

Garmy $(1995,3)$ defines the quality of deposit as a factor determined by topography, conservation capacity of soil and the extent of the cultural deposit. In İzmir historic city centre, there are insufficient data to define an exact q factor. First of all, there is no data on site's conservation capacity of archaeological deposit in İzmir historic city centre. Another analysis to define the $\mathrm{q}$ factor is the assessment of the thickness of the archaeological strata. Altimetric plans that show the altitude of all archaeological layers in plan, is a useful method for this work. However, present inquiry soundings are insufficient to examine the extent of urban archaeological resources vertically or horizontally.

So a basic evaluation that the fill in of the slope map and the inquiry soundings is made, where the analysis indicates depth increases around Fevzi Paşa Boulevard because of the alluvial floods. In addition, the slope interval between $15 \%$ and $25 \%$ enhances the conservation of urban archaeological traces. Especially, morphed grid-iron axes to the south of the State Agora and terraces parallel to the Roman Road may be evaluated as conservative factor of the topo-historical development (Figure 12).

\section{THE REAL ARCHAEOLOGICAL POTENTIAL IN IZMMIR HISTORIC CITY CENTRE}

Consequently, the real urban archaeological potential in İzmir Historic City Centre is evaluated as an outcome of the superimposition of re-ordered equi-property zones with destruction and quality of deposit analyses.

It is observed that; surely, the evaluated potential doesn't have the same characteristics in all of the defined areas. While some part of the archaeological layers have been preserved well, some parts have lost their uniqueness. Finally, twenty seven "Urban Archaeological Character Zones" are determined (Figure 13). As a matter of fact, boundaries of zones can be changed with more data on the urban dynamics changing in the future.

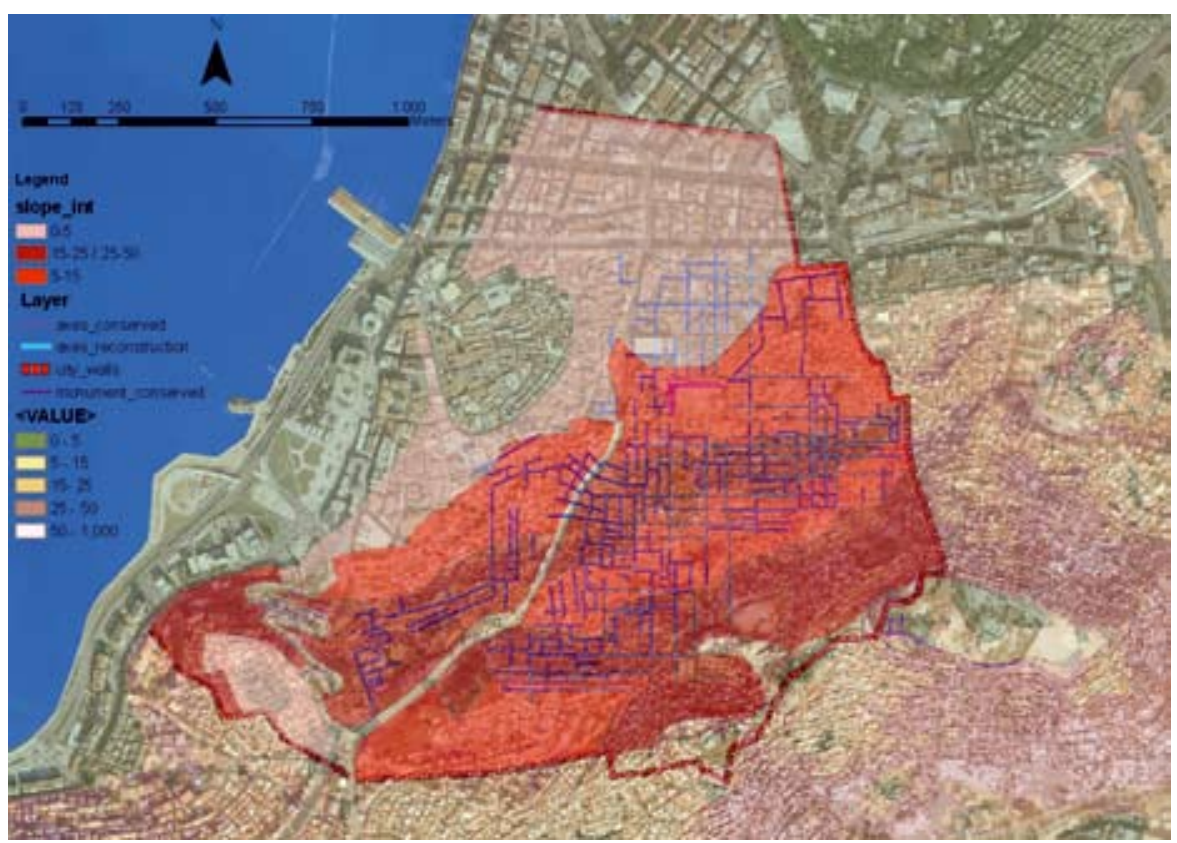


Figure 13. Urban Archaeological Character Zones in İzmir Historic City Centre according to their categories.

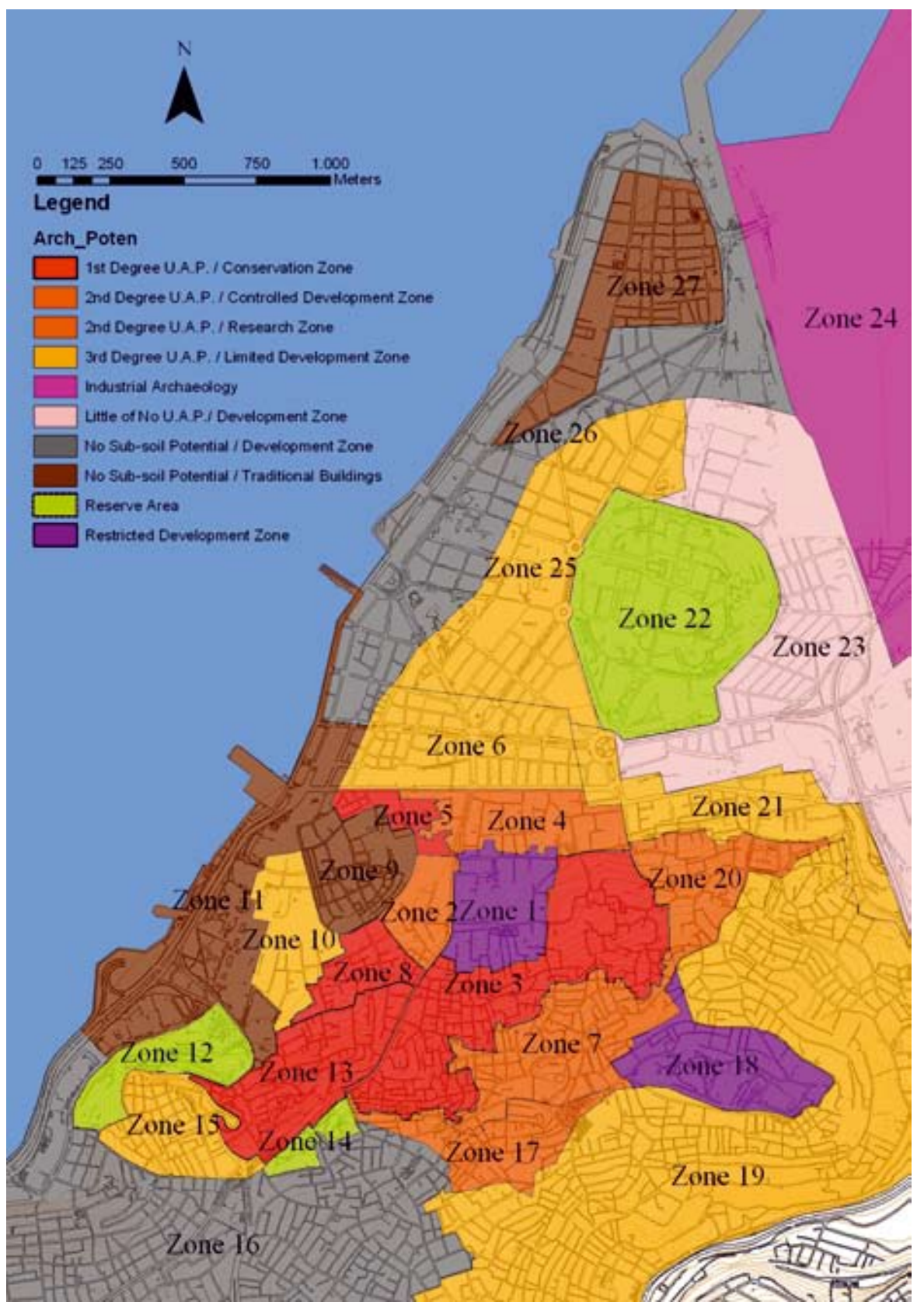

\section{Urban Archaeological Character Zones in Detail}

UACZs include an assessment of archaeological potential, threats and opportunities and research potential for future studies in each character zone. So, UACZs are policy zones including zoning-coding practices for planning and decision-making processes (Table 3).

Restricted Development Zones; Zone 1, recent boundary of the Conservation and Regeneration Project of the Agora and Its Surroundings, and Zone 18 the $1^{\text {st }}$ and $2^{\text {nd }}$ category of archaeological sites around the Kadifekale are determined as the "restricted development zone". These zones contain significant archaeological deposits of urban character relating to Roman occupation. IMMM (İzmir Metropolitan Municipality) implements a huge demolition program 
7. Reserve area term is used to define "... leaving a portion undisturbed for future research" (ICOMOS, 1990, Article-5).
Table 3. The categories of Urban Archaeological Character Zones in İzmir historic city centre according to possible potential determined by the study.

\begin{tabular}{|c|c|c|}
\hline & $\begin{array}{l}\text { DEFINITION OF PATTERN AND } \\
\text { BUILDING TYPE }\end{array}$ & $\begin{array}{l}\text { ARCHAEOLOGICAL } \\
\text { POTENTIAL AND } \\
\text { CHARACTER ZONES } \\
\end{array}$ \\
\hline Zone 1 & The State Agora Project Area & \multirow{2}{*}{$\begin{array}{l}\text { Restricted Development } \\
\text { Zone }\end{array}$} \\
\hline Zone 18 & Kadifekale & \\
\hline Zone 3 & $\begin{array}{l}\text { Traditional Buildings on Conserved Grid- } \\
\text { Iron Pattern }\end{array}$ & \multirow{4}{*}{$\begin{array}{l}\text { 1st Degree U.A.P. / } \\
\text { Conservation Zone }\end{array}$} \\
\hline Zone 5 & $\begin{array}{l}\text { Traditional Buildings on Conserved } \\
\text { Traditional Pattern of 19th Century }\end{array}$ & \\
\hline Zone 8 & $\begin{array}{l}\text { Traditional Buildings on Conserved } \\
\text { Traditional Pattern of 19th Century }\end{array}$ & \\
\hline Zone 13 & $\begin{array}{l}\text { Traditional Buildings on terraced Terrain } \\
\text { parallel to the Roman Road }\end{array}$ & \\
\hline Zone 7 & $\begin{array}{l}\text { Traditonal Buildings and Squatters on } \\
\text { Amorphed Grid-Iron Pattern }\end{array}$ & \multirow{2}{*}{$\begin{array}{l}\text { 2nd Degree U.A.P. / } \\
\text { Research Zone }\end{array}$} \\
\hline Zone 17 & Squatters & \\
\hline Zone 2 & $\begin{array}{l}\text { Mix Buildings on Conserved Traditional } \\
\text { Pattern of 19th Century }\end{array}$ & \multirow{3}{*}{$\begin{array}{l}\text { 2nd Degree U.A.P. / } \\
\text { Controlled Development } \\
\text { Zone }\end{array}$} \\
\hline Zone 4 & $\begin{array}{l}\text { Mix Buildings on Conserved Grid-Iron } \\
\text { Pattern }\end{array}$ & \\
\hline Zone 20 & $\begin{array}{l}\text { Traditional Buildings on Traditional Pattern } \\
\text { of 20th Century }\end{array}$ & \\
\hline Zone 6 & $\begin{array}{l}\text { Apartment Houses on Early Republican } \\
\text { Pattern }\end{array}$ & \multirow{6}{*}{$\begin{array}{l}\text { 3rd Degree U.A.P. / } \\
\text { Limited Development } \\
\text { Zone }\end{array}$} \\
\hline Zone 10 & $\begin{array}{l}\text { Modern Buildings on Conserved Traditional } \\
\text { Pattern of 19th Century }\end{array}$ & \\
\hline Zone 15 & $\begin{array}{l}\text { Mix Buildings on Conserved Traditional } \\
\text { Pattern of 20th Century (Zeus Akraios } \\
\text { Temple) }\end{array}$ & \\
\hline Zone 19 & Squatters & \\
\hline Zone 21 & $\begin{array}{l}\text { Transition Zone between Squatters and } \\
\text { Railway Zone }\end{array}$ & \\
\hline Zone 25 & $\begin{array}{l}\text { Apartment Houses on Early Republican } \\
\text { Pattern }\end{array}$ & \\
\hline Zone 12 & Bahribaba Park & \multirow{3}{*}{ Reserve Area } \\
\hline Zone 14 & Cici Park & \\
\hline Zone 22 & Kulturpark & \\
\hline Zone 9 & $\begin{array}{l}\text { Kemeralti Arc (Traditional Buildings on } \\
\text { Conserved Traditional Pattern of 19th } \\
\text { Century) }\end{array}$ & \multirow{3}{*}{$\begin{array}{l}\text { the Historic } \\
\text { Conservation Zones / } \\
\text { No Sub-soil Potential }\end{array}$} \\
\hline Zone 11 & Konak and Kordon Historic Site & \\
\hline Zone 27 & $\begin{array}{l}\text { Alsancak Houses on Conserved Traditional } \\
\text { Pattern of 19th Century }\end{array}$ & \\
\hline Zone 23 & Apartment Houses and Railway Zone & \multirow{2}{*}{$\begin{array}{l}\text { Little or No Sub-soil } \\
\text { U.A.P. Zones }\end{array}$} \\
\hline Zone 24 & Industrial Zone & \\
\hline Zone 16 & Apartment Houses on Modern Pattern & \multirow{2}{*}{$\begin{array}{l}\text { No Sub-soil Potential / } \\
\text { Development Zone }\end{array}$} \\
\hline Zone 26 & $\begin{array}{l}\text { Apartment Houses on Early Republican } \\
\text { Pattern (infilling area) }\end{array}$ & \\
\hline
\end{tabular}


to the western side of the Agora. However, there are not only sub-soil archaeological resources, but also archaeologically and historically sensitive axes around the State Agora. Proposed urban design project shall be re-evaluated according to conserved axes of ancient grid-iron pattern.

1st Degree Urban Archaeological Potential / Conservation Zones; Zone 3, 5, 8 and 13 are determined as the "1st Degree Urban Archaeological Potential / Conservation Zone", where there are traditional and low rise buildings. So there is no massive destruction by modern developments. Zones include sub-soil archaeological potential and archaeologically sensitive axes to set an urban continuum. Intensive urban archaeological surveys will be helpful to understand the structure of urban archaeological resources in detail. In addition, vacant plots and gardens are archaeological potential areas -reserve areas- where trial trenches and detailed inquiry soundings may be made to evaluate archaeological stratification.

2nd Degree Urban Archaeological Potential / Research Zone; Zone 7 and 17 are defined as the "2nd Degree Urban Archaeological Potential / Research Zone". Minimum intervention is required until to researches are completed in detail.

2nd Degree Urban Archaeological Potential / Controlled Development Zone; Zone 2, 4 and 20 are determined as the "2nd Degree Urban Archaeological Potential / Controlled Development Zone". A more detailed field investigation and decision making process have to be developed for these controlled development zones. Here, Inquiry Soundings and contractual solutions between urban planners, archaeologists, land owners and developers are required.

3rd Degree Urban Archaeological Potential / Limited Development; Zone 6, 10, 15, 19, 21 and 25 are determined as the "3rd degree urban Archaeological Potential / Limited Development". Limited development means agreement on the developments by public authorities and archaeologists can be allowed. Monitoring strategies like inquiry soundings or watching brief for before, during and after development should be developed to set the balance between the development and conservation.

Reserve Areas (7); Urban Parks that are at Bahribaba (Zone 12), Cici (Zone 14) and Kültürpark (Zone 22) are determined as "Urban Archaeological Reserve Areas" to analyse varying archaeological strata by developing technologies in archaeological research and documentation in future.

Historic Conservation Zones /No Sub-soil Potential; Zone 9, the arc of the ancient inner port, Anafartalar Street, known as Kemeralt1 Arc and Infill area, Konak and Kordon Historic Sites (Zone 11) and Conserved Alsancak Houses (Zone 27) that are saved after the 1922 Fire on conserved traditional pattern of the 19th century are determined as Historic Conservation Zones. These zones mainly include alluvial infill in different periods and may have archaeological and geological traces. However, their historic settings are crucial to set an urban continuum.

Little or No Sub-soil Potential Zones; Zone 23 and 24, low occupation area of Ancient Period has been wholly destroyed by apartment houses, railway and industrial activities. Therefore, zones are 
determined as "Little or No Archaeological Potential / Development Zone". In any case, the watching brief method may be developed to control the findings during the development. Also, industrial archaeology is possible in such area.

Development Zones: Zone 16 and 26 are defined as Development Zone means possibility of minimum intervention / destruction on urban archaeological resources.

\section{CONCLUSION}

Exploratory case study is a basic example to examine the defined methodological framework. While İzmir Historic City Centre are analyzed step by step, problems and potentials of handling archaeological resources in the planning process, reflecting general problems in multilayered historic city centres in Turkey are observed. Therefore, developed strategies for İzmir shall be the concern of everyone, to cope with urban archaeological potential of historic city centres.

In this context, setting an urban archaeological database with recent data in İzmir Archaeological Museum and İzmir Regional Conservation Council should be primary concern of related authorities. A comprehensive database needs not only accurate and detailed data, but also financial, administrative and technical supports. At that point, the responsibility of İMM with financial and technical capabilities is crucial, rather than the İzmir Archaeological Museum and Regional Council which have less capabilities.

On the other hand, the formation of such a comprehensive database is a long-term work, so basic strategies should be developed for the recent planning process. Strategies can be enhanced by the basic documentation used in this study. This documentation should be supported by more proper extensive and intensive urban archaeological surveys to define preliminary character zones. These surveys may be used in UAD, and then the boundaries of the character zones can be modified in the future. In addition to surveys, some trial trenches or inquiry soundings shall be made at critical points where probable development pressure may increase in the near future.

Furthermore, recent planning studies and site decisions should be updated according to conserved archaeological traces in detail. Once this is accomplished, an Urban Archaeological Management Guideline including policies on presenting archaeological resources, conservation by documentation and new construction should be maintained.

\section{ABBREVIATIONS}

UAD; Urban Archaeological Database

UACZ; Urban Archaeological Character Zone

IMM; İzmir Metropolitan Municipality

ICOMOS; International Council of Monuments and Sites

$\mathrm{CoE}$; the Council of Europe

\section{BIBLIOGRAPHY}

ADDYMAN, P. (2003) Urban Archaeology-Where Now, FSA at the Society of Antiquaries of London, Piccadilly. 
AKURGAL, E. (1970) Ancient Civilizations and Ruins of Turkey -From Prehistoric Times until the end of the Roman Empire, Haşet Kitabevi, İstanbul.

ALPAN, A. (2005) Integration of Urban Archaeological Resources to Everyday Life in the Historic City Centres Tarragona, Verona and Tarsus, unpublished Master's Thesis, METU, Ankara.

ALKIN, B. (1968) Anatolien, Cenevre.

ATAY, Ç. (1998) Osmanlı'dan Cumhuriyete İzmir Planları, Ajans-Türk Basımevi, Ankara.

AYKAÇ, P. (2008), Determination of Presentation Principles for Multi-Layered Historical Towns Based fn Cultural Significance Case Study: Tarsus, unpublished Master's Thesis, METU, Ankara.

BEAN, G.E. (1966) Aegean Turkey, London.

BELGE, B. (2005) Urban Archaeological Issues and Resources in Izmir Historic City Centre: An Exploratory Case Study, unpublished Master's Thesis, METU, Ankara.

BERTIN, J. (1981) Graphics and Graphic Information Processing, Walter de Gruyter, Berlin.

BEYHAN B., BELGE. B., ZORLU F. (2010) Özgür ve Açık Kaynaklı Masaüstü CBS Yazılımları Üzerine Karsılastırmalı ve Sistemli Bir Degerlendirme / Free and Open Source Desktop GIS Software Programs: A Comparative and Systematic Evaluation, Harita Dergisi, $143 ; 45-61$.

BİLGIN, A.G. (1996) Urban Archaeology: as the Bases for the Studies on the Future of the Town Case Study: Bergama, unpublished Master's Thesis, METU, Ankara.

BİLGiN (ALTINÖZ), A. G. (2002) Assessment of Historical Stratification in Multi-layered Towns As a Support for Conservation Decision-Making Process; A Geographic Information Systems (GIS) Based Approach Case Study: Bergama, unpublished Ph.D. Thesis, METU, Ankara.

CADOUX, C.J. (1938) Ancient Smyrna; A History of the City from the Earliest Times to 324 A.D., Basil Blackwell, Oxford.

CANPOLAT, E. (1953) İzmir: Kuruluşundan Bugüne Kadar, İstanbul.

CoE / the Council of Europe (1989) Recommendation on the Protection and Enhancement of the Archaeological Heritage in Context of Town and Country Planning Operations.

CoE / the Council of Europe (2000) Archaeology and the Urban Project, a European Code of Good Practice, Cultural Heritage Committee, Strasbourg.

COHEN, N. (2001) Urban Planning Conservation and Preservation, McGrawHill.

ÇIRAK (ALTINÖRS), A. (2010) Bir Planlama Stratejisi Olarak Arkeolojik Envanterleme ve Kentsel Arkeolojik Değer Yönetimi: İzmir Tarihi Kent Merkezi, unpublished Ph.D. Thesis, Dokuz Eylül University, İzmir.

DELAUNAY, C. (1984) Collaboration between Planners and Archaeologists, Archaeology and Planning, the Colloquy organized jointly by the Council of Europe and the Region of Tuscany, Florence. 
EC / European Commission (2006) Appear Method, a Practical Guide for The Management of Enhancement Projects on Urban Archaeological Sites, Research Report 30/4.

FOUSEKI K., SANDES, C. (2009) Private Preservation versus Public Presentation: The Conservation for Display of In Situ Fragmentary Archaeological Remains in London and Athens, Papers from the Institute of Archaeology, 19; 37-54.

GARMY, P. (1995) Urban Archaeology in France, Committee on Cultural Heritage, European Plan for Archaeology, Group of Specialist on Urban Archaeology, CE, Strasbourg.

HESTER, A. D. (1989) Public Archaeology Forum, Journal of Field Archaeology, 16(2) 233-40.

ICOMOS (1990) Charter for the Protection and Management of the Archaeological Heritage, Valetta, Malta.

İzmir Büyükşehir Belediyesi (2003) Küllerinden Doğan Şehir, Kültür Yayınları, İzmir.

KILIÇ, M., GÜLBAY, O. (2010), The Değirmentepe Temple at Smyrna, TÜBAAR (Turkish Academy of Science, Journal of Archaeology), 13; 11326.

KUBAN, D. (2001) İzmir'in Tarihsel Yapısının Özellikleri ve Koruması ile İlgili Rapor, Türkiye'de Kentsel Koruma; Kent Tarihleri ve Koruma Yöntemleri, Tarih Vakfı, İstanbul; 49-105.

MÜLLER, W.W. (1963) Die Stadtbefestigungen von Izmir, Sığacık und Çandarl, Deutsches Archaologisches Institut Ableilung, Istanbuler Mitteilunge, İstanbul.

NAUMANN, R., KANTAR, S. (1950) Die Agora Von Smyrna, Forschungen 17, İstanbul.

ÖZKUT, D. (1997) A Guideline for Conservation of Historical Commercial Centre "Punta" in Izmir, unpublished Master Thesis, METU, Ankara.

PINAR, İ. (2001) Hacılar, Seyyahlar, Misyonerler ve İzmir, Yabancıların Gözüyle Osmanlı Döneminde İzmir 1608-1918, İzmir Büyükşehir Belediyesi Kültür Yayınları, İzmir.

PPG16 / Planning Policy Guidance 16 (1990) Planning and Archaeology, Secretary of State for the Environment.

PPS 5 / Planning Policy Statement-5 (2010), Planning for Historic Environment, Communities and Local Government, TSO.

POCOCKE, R. (1972) Voyage de Richard Pococke, Chapter V, Paris.

SOMMELLA, P. (1984), Methodology of Archaeological Research in Urban Areas, Archaeology and Planning, the Colloquy organized jointly by the Council of Europe and the Region of Tuscany, Florence.

TANER, T., ECEMIŞ, S., AYDOĞAN, M. (2002) Kemeraltı Koruma Amaçlı Imar Planı Revizyonu Raporu, Dokuz Eylül University, Faculty of Architecture, Department of City and Regional İzmir.

TUNA, N. (1999) Turkey, Report on the Situation of Urban Archaeology in Europe, the Council of Europe Publishing; 217-28. 
TUNA, N. (2003) İstanbul Suriçi'nde Kentsel Arkeolojik Kültür Mirası, İstanbul Dergisi, Tarih Vakf1, 46; 88-93.

WHEATLEY, D., GILLINGS, M. (2002) Spatial Technology and Archaeology, the Archaeological Applications of GIS, Taylor \& Frances, London.

Alındı: 08.05.2012; Son Metin: 18.09.2012

Anahtar Sözcükler: ideal ve gerçek kentsel arkeolojik potansiyel, izmir tarihi kent merkezi, çok katmanlı tarihi kent merkezleri, katmansal planlar, eş-değer alanları, kentsel arkeolojik karakter bölgeleri.

\section{KENTSEL PLANLAMADA TOPRAK ALTI KENTSEL ARKEOLOJIK KAYNAKLAR, İZMIR TARIHII KENT MERKEZI}

Türkiye'deki tarihi kent merkezlerinin birçoğu erken dönemlerden itibaren sürekli olarak yerleşim yeridir. Bu nedenle, tarihi kent merkezleri kentsel arkeoloji çalışma alanı için önemli araştırma potansiyeli taşımaktadır. Kentsel planlama alanı açısından baktığımızda ise, kentsel arkeolojik değerler planlama sürecine etkin bir biçimde dâhil edilebilirse, tarihi kent merkezlerinin çok katmanlı yapısının hem kentlerin tarihsel sürekliliğinin bir göstergesi, hem de kentli bilincini güçlendirebilecek bir öğe olacağ 1 açıktır.

Fakat Türkiye'deki güncel politikalar ve stratejiler kentsel arkeolojik değerlerin, özellikle görünmeyen toprak altı değerlerin, planlama ve karar alma süreçlerine katılımına olanak sağlamamaktadır. Bu çalışmada, Türkiye'deki tarihi kent merkezlerinin planlama sürecine kentsel arkeolojik değerlerin dâhil edilebilmesi için temel bir yöntemsel çerçeve tanımlanmaktadır.

Çalışma alanı olarak çok katmanlı bir kent yapısına sahip olan İzmir Tarihi Kent Merkezi seçilmiştir. Çalışma kapsamında kentsel arkeolojik değerler için yönetim stratejilerinin tanımlanabilmesi amacıyla eş-değer alanları (ideal arkeolojik potansiyelin tanımlanması için temel birimler) ve kentsel arkeolojik karakter bölgeleri (planlama ve koruma politikalarının tanımlanması için temel birimler) kavramları geliştirilmiştir.

BURAK BELGE; B.CRP, M.CP, Ph.D.

Received B.CRP (2002), M.CP (2005) and Ph.D. (2012) degrees at METU. Worked in various urban planning and research projects at METU-TAÇDAM (Centre for Research and Assessment of Historic Environment) and METU-MATPUM (Research and Implementation Centre for Built Environment and Design). Currently a member of the Department of City and Regional Planning at Mersin University. burakbelge@mersin.edu.tr, burak.belge@gmail.com 